\title{
ASPECTOS DA DECLARAÇÃO DE INCONSTITUCIONALIDADE SEM PRONÚNCIA DE NULIDADE
}

\section{Emerson Ademir Borges de Oliveira*}

Resumo: Pode a Constituição se curar? O que persegue o presente artigo é a resposta sobre como lidar com as ofensas perpetradas em face da Constituição que se construam sobre situações fáticas consolidadas. Muitas vezes a simples declaração de inconstitucionalidade, seja desde o início, na teoria da nulidade, seja para o futuro, na teoria da anulabilidade, ou seja, em conjugação de ambos, com a modulação temporal de efeitos, não apresentará respostas positivas à ofensa constitucional. A metodologia para o desenvolvimento do trabalho é eminentemente bibliográfica e jurisprudencial.

Palavras-chave: Constitucionalização superveniente. Cicatrização constitucional. Força normativa dos fatos. Inconstitucionalidade. Pronúncia de nulidade.

\section{ASPECTS OF THE DECLARATION OF UNCONSTITUTIONALITY WITHOUT NULLITY EFFECTS.}

\begin{abstract}
Can the Constitution be healed? The aim of this article is the answer on how to deal with offenses committed in the face of the Constitution which are built on consolidated factual situations. Often the simple declaration of unconstitutionality, either from the beginning, the theory of nullity, or for the future, in annulability theory, or in conjunction both with the temporal modulation effects will not show positive responses to the constitutional offense. The methodology for the development work is eminently literature and case law.
\end{abstract}

Keywords: Incidental constitutionalisation. Constitutional healing. Normative force of facts. Unconstitutionality. Null pronunciation.

\section{Introdução}

A tormentosa questão da nulidade da lei constitucional tem gerado discussões profundas no Direito Constitucional, no Brasil e ao redor do mundo. Até alguns anos atrás, insistíamos na ideia mais concisa de que a lei inconstitucional nasce morta, sendo nula desde seu início. Ou como abordaria a máxima do judicial review norte-americano, the inconstitutional statute is not law at all (WILLOUGHBY, 1910, p.9-10).

\footnotetext{
* Mestre e Doutor em Direito do Estado pela Universidade de São Paulo. Pós-Doutor em Democracia e Direitos Humanos pela Universidade de Coimbra. Coordenador-Adjunto e Professor permanente do Programa de Mestrado e Doutorado em Direito da Universidade de Marília. Advogado e parecerista. E-mail: emerson@unimar.br. Endereço postal: Av. Hygino Muzzi Filho, 1001 - Pró-Reitoria de Pós-Graduação, CEP 17525-010, Marília/SP.
} 
Ideia que, frise-se, remonta, justamente, ao controle de constitucionalidade ianque, já que no modelo de jurisdição constitucional europeu, desde a concepção kelseniana, tem-se optado pela ideia de anulabilidade das leis, opondo-se ao regime segundo o qual a lei inconstitucional não deveria ter produzido qualquer efeito, mesmo que tivesse atuado por muito tempo sobre a vida das pessoas.

Mas, mesmo o sistema do judicial review viu o tempo como grande inimigo das declarações de simples nulidade, sobrepondo-se ao modelo uma ideia de política judiciária e de discussão, justa, acerca dos efeitos das declarações frias de inexistência de qualquer efeito, durante anos, da lei inconstitucional.

Mais do que isso, as Cortes responsáveis pelo controle de constitucionalidade, exclusivamente ou não, começaram a lidar com questões ainda mais problemáticas: casos em que, a despeito da inconstitucionalidade da lei ou do ato normativo, a sua declaração, ainda que ex nunc, poderia gerar efeitos mais danosos do que a sua manutenção, no campo jurídico, econômico, político e social.

Nessa seara, com inegável contribuição do Tribunal Federal Alemão (Bundesverfassungsgericht) desenvolveram outras técnicas de controle que tinham por escopo buscar no Legislativo o apoio para a superação da situação até então inconstitucional. Dentre essas técnicas, destacaram-se a declaração de inconstitucionalidade sem pronúncia de nulidade (Unvereinbarkeitserklärung) e o apelo ao legislador (Appellentscheidung), que preferia a lógica mais adequada de leis ainda constitucionais (noch verfassungsgemäss), vista como uma "[...] peculiar sentença de rejeição de inconstitucionalidade", com conteúdo preventivo, "operando no "campo preliminar da patologia constitucional"” (MENDES, 2007, p.406).

Para além, existem situações em que a inconstitucionalidade, nem mesmo para o futuro, pode salvaguardar as relações consubstanciadas em seu regime, tidas, por assim dizer, como consumadas, mas com efeitos pujantes ad eterno. Um desses casos, entre nós, é o leading case do Município Luís Eduardo Magalhães (ADI 2.240/BA), em que o Supremo Tribunal Federal (STF) brasileiro teve de lidar com questões que levam ao repensar sobre os efeitos da lei inconstitucional, mormente quando os fatos conduzem ao Direito, e não o contrário. E, especialmente, quando o Congresso Nacional do Brasil promulgou a Emenda Constitucional 57, de 2008, convalidando os Municípios criados sem as diretrizes constitucionais. 
Essas mesmas questões nos conduzem a uma aceitação tímida, num primeiro momento, da "teoria da constitucionalização superveniente", algo até então rechaçado por nosso modelo de controle de constitucionalidade, embora essa teoria dependa da mudança posterior do próprio paradigma constitucional. Há situações, no entanto, que a Constituição sequer é alterada e, diante disso, ainda nos perguntamos se a situação admitiria o estancamento da "sangria constitucional".

Nota-se que não se trata de dar sobrevida ao teor inconstitucional, esperando que o legislador faça as correções necessárias, mas aceitar que o mal causado pela norma inconstitucional já cicatrizou e a situação, antes de ofensa, passa a ser aceita pela consolidação fática, desde que, evidentemente, não tenha tido a intenção clara de ofender a Constituição e os efeitos da declaração de inconstitucionalidade sejam social, política, econômica ou juridicamente piores do que a sua manutenção.

\section{0 problema do modelo de controle e a superação da dicotomia nulidade-anulabilidade}

Como é cediço, o Brasil adota um sistema misto de controle de constitucionalidade, mas que fora inaugurado pelo sistema difuso, em 1891, adotando-se o método praticado nos Estados Unidos de 1803. Posteriormente, em 1965, passamos a adotar, também, o modelo de jurisdição constitucional concentrada europeu.

Todavia, por influência clara do primeiro sistema adotado (judicial review), o Brasil acabou se enamorando pela doutrina da nulidade da lei inconstitucional, vista como algo que nunca deveria ter produzido qualquer efeito jurídico, ante sua clara inexistência de razão de ser. Isto é, aquilo que nasce em desacordo com a Constituição, na realidade, não nasceu.

Mas, até mesmo a criadora do modelo, a Suprema Corte, resolveu dobrar-se à lógica de que a pecha de nulidade nem sempre responde adequadamente aos problemas de inconstitucionalidade. Em Linkletter v. Walker, 1965, concluiu que "[...] a Constituição não proíbe nem exige efeito retroativo". A questão da retroatividade ou não do efeito do julgado passaria a ser questão de política judiciária e não mais uma vinculação à declaração de nulidade. 
A retroatividade decorrente do efeito ex tunc da nulidade passaria, então, a ser um assunto de política judiciária, que a Suprema Corte entendeu por bem usar quando demandada acerca da nulidade das condenações baseadas na inadmissibilidade de provas obtidas ilegalmente, conforme reconhecido em Mapp v. Ohio, em 1961 (MENDES, 2012, p.572-573).

Como afirma Mendes (2012, p.575-576), a doutrina constitucionalista norteamericana evoluiu de um primeiro momento de declaração de inconstitucionalidade com efeitos amplos, limitados e retroativos (limited retrospectivity) para um momento de admissão de superação prospectiva da inconstitucionalidade (prospective overruling), limitada (limited prospectivity) ou ilimitada (pure prospectivity), diferenciando ambas acerca da aplicação no caso concreto e futuro ou nem mesmo para aquele caso concreto.

A questão, desde o princípio, é tratada de forma diferente pelo modelo austríaco kelseniano. Naquele caso, é reconhecida a função do Tribunal enquanto legislador negativo, constituindo-se a nulidade e não apenas declarando-a. Como já salientado, para “[...] o Verfassungsgerichtshof, a Corte Constitucional Austríaca, a lei inconstitucional é ato com força jurídica até que ocorra sua cassação" (BORGES DE OLIVEIRA, 2015, p.225).

Kelsen (2007, p.177), o criador do modelo austríaco, já ressaltava em suas lições: “A decisão do tribunal constitucional, quando o pedido é acolhido, deve pronunciar a anulação do ato contestado de maneira que apareça como consequência da própria decisão”. Excepcionase quanto ao efeito declarativo, o próprio caso concreto submetido a exame, em que poderá operar retroatividade.

Assim, no controle austríaco, a "[...] pronúncia de inconstitucionalidade tem eficácia ex nunc (a contar da data da publicação do julgado), salvo se o Tribunal estabelecer prazo para a entrada em vigor da cassação", a ocorrer em no máximo dezoito meses da decisão. De qualquer forma, mantém-se a retroatividade para o caso concreto, entendendo em tal característica todos os que possuam o mesmo objeto e estejam pendentes de julgamento na Corte (MENDES, 2012, p.577).

Em território espanhol, mesmo diante da inexistência de regulação temática, a Corte Constitucional admite a decisão de inconstitucionalidade sem declaração de nulidade. Assim, por exemplo, na STC 13/92/17, a Corte reconheceu que graves perturbações ou prejuízos aos interesses coletivos, como situações consolidadas e políticas econômicas ou financeiras, podem justificar uma decisão desse tipo (MENDES, 2012, p.578-579). 
Diferentemente, Portugal admite expressamente, no artigo 282 de sua Constituição, que razões de segurança jurídica, equidade ou interesse público de excepcional relevo justifiquem a modulação da decisão para que não produza efeitos retroativos. No entanto, no direito luso, como aponta Canotilho (2007, p.1018), não há espaço para sentenças que apenas declarem a inconstitucionalidade, sem produzir efeito de nulidade, exceto pela situação acima, tendo em vista que a publicação oficial do Tribunal consubstancia limite temporal absoluto: “[...] uma norma não pode continuar a produzir efeitos após a publicação da decisão que a declare inconstitucional com força obrigatória geral”.

$\mathrm{Na}$ Alemanha, embora prepondere o entendimento acerca da nulidade da lei declarada inconstitucional, desenvolveram-se técnicas para driblar os efeitos retrospectivos de tal declaração, como a "declaração de inconstitucionalidade sem a pronúncia de nulidade" (Unvereinbarkeitserklärung) e o "apelo ao legislador" (Appellentscheidung) ${ }^{1}$.

Como ressalta Mendes (2012, p.583), ainda no começo do século passado, sob a égide da Constituição de Weimar, Triepel sustentava no caso Referat que questões com alto índice político, quando submetidas à Corte, deveriam receber respostas fora da tradição processual, em face da incompatibilidade desta em atender aquelas questões. Ainda, Walter Jellinek já defendia que a declaração de nulidade deveria ser utilizada apenas quando bastasse para a solução do problema submetido à análise do Reichsgericht.

O apelo ao legislador pode se mostrar como técnica adequada justamente em casos de "leis ainda constitucionais" (noch verfassungsgemäss). A técnica do Appellentscheidnung deriva da práxis do Tribunal Constitucional Federal Alemão e se mostra, como ressalta Mendes (2007, p.406) como uma "[...] peculiar sentença de rejeição de inconstitucionalidade", com conteúdo preventivo, “[...] operando no "campo preliminar da patologia constitucional'” (MENDES, 2007, p.406).

Além de operar no campo pedagógico, no sentido de se exortar o dever constitucional de legislar, Bulos (2010, p.364) ressalta que o "apelo ao legislador" também serve para "preservar situações constituídas em face de mudanças nas relações fáticas e jurídicas" e "para atestar se, realmente, houve ofensa constitucional".

Tais conteúdos conferem, na visão de Mendes (2007, p.396), maior relevo ao eterno binômio direito-política, tornando mais intrínseca e dependente a relação entre ambos.

\footnotetext{
${ }^{1}$ O termo fora criado pela juíza Emmi Agathe Karola Margarete Wiltraut Rupp-von Brünneck, do Tribunal Constitucional Federal Alemão, em artigo de 1970 intitulado Darf das Bundesverfassungsgericht an den Gesetzgeber appellieren?
} 
Na Alemanha é comum apontar a decisão proferida em 4 de maio de 1954 acerca do Estatuto do Sarre (Sarrstatut) como ponto de partida para a construção do "apelo ao legislador". Naquela ocasião, a Corte manifestou-se no sentido de que providências legislativas tomadas para superar o estatuto de ocupação, ainda que imperfeitas, contribuíam com uma gradual compatibilização da situação jurídica com a Grundgesetz. E por essa razão eram leis ainda constitucionais (MENDES, 2007, p.403-404).

Embora essa ampla variação de decisões tenha raízes germânicas, sendo a princípio incompatível com o modelo norte-americano, é certo que há algum tempo os Tribunais estadunidenses têm abandonado a prática meramente expurgatória da norma inconstitucional, para assumir um papel mais impositivo de obrigações positivas.

Na temática da democracia, o Tribunal Alemão entendeu, quanto à divisão dos distritos eleitorais, que as "mudanças fáticas" conduziriam a um "processo de inconstitucionalização", eis que não mais estava sendo atendido o princípio de igualdade eleitoral e, negando-se a declarar a inconstitucionalidade da legislação, apelou ao legislador para efetuar as modificações necessárias para reduzir a discrepância existente para patamares toleráveis ${ }^{2}$.

Naquela ocasião, em 22 de maio de 1963, o Tribunal deparou-se com o velho problema da mudança da realidade fática sem alteração legislativa, sendo que a divisão se baseava na estrutura demográfica de 1949. Negando-se a declarar a inconstitucionalidade, a Corte salvaguardou a democracia alemã, evitando a invalidade das últimas eleições e, por via de consequência, do próprio Parlamento e do Governo. E, diante do fato de já ter se encerrado a legislatura anterior, inexistiria a possibilidade de se promulgar a lei adequada, caindo-se em um vazio institucional (MENDES, 2007, p.408).

Evidentemente, o Tribunal não pode deixar de levar em conta que a alteração fática não havia sido constatada no momento da promulgação da lei atacada e a dificuldade em identificar a questão ${ }^{3}$. Diante da decisão consciente da Corte, em 1964, o Parlamento publicou nova lei, adaptando os distritos eleitorais.

\footnotetext{
${ }^{2}$ BVerfGE: $16,130$.

${ }^{3}$ É o que destacou o próprio Bundesverfassungsgericht: "A dificuldade de precisar o momento exato em que a divisão dos distritos eleitorais, anteriormente legítima, tornou-se incompatível com a Constituição assenta-se, principalmente, no fato de que esse desenvolvimento caracteriza-se por uma instável fase de transição, o que acabou por dificultar que esse desenvolvimento pudesse ser previsto, em sua integridade, com a necessária segurança". BVerfGE: 16, 130 (142/143).
} 
Já no tocante à "declaração de inconstitucionalidade sem a pronúncia de nulidade" (Unvereinbarkeitserklärung), outra técnica também desenvolvida entre os alemães, parte do efeito pedagógico de se reconhecer que determinada lei é inconstitucional, mas, na prática, percebe que a retirada da lei inconstitucional do sistema jurídico traz mais malefícios do que benefícios. Por isso, não lhe declara a nulidade.

Como ressalta Urbano (2016, p.112), a técnica fora criada pela jurisprudência a despeito da limitação constante da Seção 78 da Lei Orgânica da Corte Constitucional Federal Alemã, que se resume à hipótese de nulidade da lei (Gesetz über das Bundesverfassungsgericht). Tem sido aplicado nas seguintes situações:

1) Relativamente ao direito transitório: o juiz prescinde da declaração de inconstitucionalidade quando o legislador não tinha outra alternativa, dado o contexto histórico existente;

2) Quando a inconstitucionalidade não é evidente, designadamente, por motivos de segurança pública;

3) Quando a ausência da norma inconstitucional é menos adequada do que a própria manutenção da norma constitucional;

4) Quando estão em causa disciplinas discriminatórias.

A propósito, o próprio Tribunal destaca:

Uma lei inconstitucional geralmente é invalidada pelo Tribunal Constitucional Federal. A nulidade também tem um efeito sobre o passado e, legalmente, leva a um estado como se a lei nunca tivesse sido promulgada. Em certos casos, o Tribunal Constitucional Federal apenas declara uma disposição legal incompatível com a Lei Básica e estipula a partir de que data não pode mais ser usada. Isto acontece especialmente quando o legislador possui diferentes maneiras de eliminar a violação constitucional ou se as desvantagens da revogação imediata são maiores do que as desvantagens para validade contínua de transição. Este último é frequentemente o caso das leis fiscais, porque, caso contrário, a base legal para a cobrança de impostos desapareceria total ou parcialmente. No período de transição, o legislador pode emitir um padrão constitucional. Em casos raros, o próprio Tribunal Constitucional Federal determina disposições transitórias ${ }^{4}$.

Como solução pouco ortodoxa, a autora supramencionada ressalta que a técnica decisória acaba aproximando-se da vacatio legis, de forma que o legislador possa intervir e

\footnotetext{
4 BUNDESVERFASSUNGSGERICHT. Wirkung der Entscheidungen. Disponível em: <https://www.bundesverfassungsgericht.de/DE/Verfahren/Wichtige-Verfahrensarten/Wirkung-derEntscheidung/wirkung-der-entscheidung_node.html>. Tradução nossa.
} 
resolver o vazio jurídico. Mais do que isso, a técnica se afasta das sentenças mais comuns do direito alemão, com eficácia ex tunc, para assumir uma postura mais próxima do direito austríaco, ex nunc. Ademais, sua utilidade decorre não da suspensão da lei declarada inconstitucional, mas da continuidade de sua aplicação, o que tem sido exceção nas decisões do Tribunal Constitucional alemão (URBANO, 2016, p.112-113). Explica-se, pouco haveria de novo na técnica se ela simplesmente suspendesse a lei declarada inconstitucional, uma vez que cessariam seus efeitos e cairíamos no vácuo legislativo. Sua lógica decorre da continuidade provisória de aplicação, à espera de uma solução legislativa urgente.

$\mathrm{Na}$ realidade, estas decisões, destinadas às questões mais políticas do que jurídicas, elucidam a preocupação, desde o século passado, “[...] com o perigo da adoção pura e simples, pela jurisdição constitucional, das formas de decisão consagradas pela jurisdição ordinária” (MENDES, 1993, p.64). No início dos anos 80, a técnica já era tão difundida na Corte que se equiparava às decisões de nulidade simples.

É preciso frisar, no entanto, que a declaração de inconstitucionalidade sem pronúncia de nulidade esconde o risco de cair ao arbítrio puro do Tribunal, vez que não existem parâmetros seguros sobre as ocasiões em que isso deve ocorrer. Evidente que a segurança jurídica diante de tais questões pode ficar, de certa forma, ameaçada, o que não inviabiliza a medida. Antes, recomenda-lhe prudência.

De qualquer forma, a aplicação da lei declarada inconstitucional é algo que encontra respaldo no próprio sistema jurídico, conforme indica Pestalozza (1976, p.565-566). Sua legitimidade decorre da própria Constituição, na medida em que a sua suspensão pode gerar ofensas a direitos fundamentais, conforme decidira a Corte no julgamento acerca da nacionalidade das crianças nascidas nos "casamentos mistos".

Entre os norte-americanos, em Colegrove v. Green, em 1946, o juiz Frankfurter entendeu que os distritos eleitorais, como estavam divididos, eram inconstitucionais, mas a decisão de nulidade seria um mal pior do que a manutenção da divisão, ante o fato de que o Estado de Illinois ficaria sem uma divisão válida, aguardando-se, enfim, uma solução do legislador (O’BRIEN, 1991, p.111).

No Brasil, como é cediço entre os constitucionalistas, a possibilidade de modulação se desenvolveu a partir dos artigos 27 da Lei 9.868/99 e 11 da Lei 9.882/99, admitindo-se que

${ }^{5}$ BVerfGE 37, 217. 
razões de segurança jurídica ou excepcional interesse público poderiam justificar a modulação temporal dos efeitos da declaração de inconstitucionalidade.

Nota-se que, ao redor do mundo, a dicotomia da anulabilidade-nulidade, decorrente do sistema de controle adotado, acabou perdendo seu sentido, mormente em países como o nosso que acabaram adotando um sistema misto de controle de constitucionalidade. No mais, mesmo países de controle difuso, que sempre defenderam a nulidade da lei inconstitucional, tiveram de lidar com a realidade da decisão útil, isto é, aquela em que não se recomenda a nulidade porque seus efeitos seriam perniciosos diante dos fatos consumados.

\section{Constitucionalização superveniente e cicatrização constitucional}

Entre nós, ademais, o Supremo teve em exame uma questão bastante tormentosa em que a principal discussão acabou se tornando justamente o efeito a ser conferido à declaração de inconstitucionalidade. Trata-se da Ação Direta de Inconstitucionalidade 2.240/BA.

Nesta ação buscou-se a declaração de inconstitucionalidade da Lei Estadual da Bahia 7.619/00, que criou o Município de Luís Eduardo Magalhães ${ }^{6}$, posteriormente à Emenda Constitucional 15/96, que exige Lei Complementar Federal a determinar as diretrizes para a criação de novos municípios, como a necessidade de consulta prévia, mediante plebiscito, das populações envolvidas, divulgação de Estudos de Viabilidade Municipal e períodos, conforme artigo $18, \S 4^{\circ}, \mathrm{CF}$, sem que a referida lei estadual tivesse obedecido qualquer dessas diretrizes.

Ora, o desrespeito às diretrizes da EC 15 na criação do referido município, em uma leitura tradicional, comportaria o entendimento de que não apenas a sua própria criação seria nula, como todos os atos municipais praticados desde então. Estariam rasgados, com a declaração, 16 anos de atos públicos locais.

O Supremo visualizou uma hipótese excepcional, em face de sua consolidação desde 2000, e a nulidade no atual estágio municipal acarretaria grave risco à segurança jurídica. Pior do que isso: a nulidade, com a justificativa de respeito à Constituição, implicaria em um mal

\footnotetext{
${ }^{6}$ O Município fora fundado em 30 de março de 2000 e, conforme o Censo de 2015, possui população de 79.162 habitantes.
} 
ainda maior do que a manutenção do estado de coisas. Na ocasião, o STF preferiu sair pela tangente, concedendo-se prazo de 24 meses para a regularização jurídica do Município, nos termos da EC $15^{7}$.

Houve uma clara opção pela situação consolidada de fato, optando-se pela apresentação posterior dos requisitos constitucionais como medida para atender às exigências da Constituição, referendando-se os fatos.

Ocorre que o legislador constituinte acabou escolhendo a saída da "constitucionalidade superveniente". Para compreender, primeiramente, o conceito, devemos ter em mente que, em algumas situações, a lei é inconstitucional diante do parâmetro - texto constitucional - válido no momento de sua criação. Posteriormente, advém mudanças no texto constitucional - ou mesmo uma nova Constituição - e aquela lei que era inconstitucional não é mais incompatível com o texto atual, "constitucionalizando-se".

Como já dissemos, em face da adoção da teoria da nulidade, pela qual a lei inconstitucional nasce morta, não haveria possibilidade de constitucionalização superveniente.

\footnotetext{
7 “1. O Município foi efetivamente criado e assumiu existência de fato, há mais de seis anos, como ente federativo. 2. Existência de fato do Município, decorrente da decisão política que importou na sua instalação como ente federativo dotado de autonomia. Situação excepcional consolidada, de caráter institucional, político. Hipótese que consubstancia reconhecimento e acolhimento da força normativa dos fatos. 3. Esta Corte não pode limitar-se à prática de mero exercício de subsunção. A situação de exceção, situação consolidada - embora ainda não jurídica - não pode ser desconsiderada. 4. A exceção resulta de omissão do Poder Legislativo, visto que o impedimento de criação, incorporação, fusão e desmembramento de Municípios, desde a promulgação da Emenda Constitucional n. 15, em 12 de setembro de 1.996, deve-se à ausência de lei complementar federal. 5. Omissão do Congresso Nacional que inviabiliza o que a Constituição autoriza: a criação de Município. A não edição da lei complementar dentro de um prazo razoável consubstancia autêntica violação da ordem constitucional. 6. A criação do Município de Luís Eduardo Magalhães importa, tal como se deu, uma situação excepcional não prevista pelo direito positivo. 7. O estado de exceção é uma zona de indiferença entre o caos e o estado da normalidade. Não é a exceção que se subtrai à norma, mas a norma que, suspendendo-se, dá lugar à exceção - apenas desse modo ela se constitui como regra, mantendo-se em relação com a exceção. 8. Ao Supremo Tribunal Federal incumbe decidir regulando também essas situações de exceção. Não se afasta do ordenamento, ao fazê-lo, eis que aplica a norma à exceção desaplicando-a, isto é, retirando-a da exceção. 9. Cumpre verificar o que menos compromete a força normativa futura da Constituição e sua função de estabilização. No aparente conflito de inconstitucionalidades impor-se-ia o reconhecimento da existência válida do Município, a fim de que se afaste a agressão à federação. 10. O princípio da segurança jurídica prospera em benefício da preservação do Município. 11. Princípio da continuidade do Estado. 12. Julgamento no qual foi considerada a decisão desta Corte no MI n. 725, quando determinado que o Congresso Nacional, no prazo de dezoito meses, ao editar a lei complementar federal referida no $\S 4^{\circ}$ do artigo 18 da Constituição do Brasil, considere, reconhecendo-a, a existência consolidada do Município de Luís Eduardo Magalhães. Declaração de inconstitucionalidade da lei estadual sem pronúncia de sua nulidade 13. Ação direta julgada procedente para declarar a inconstitucionalidade, mas não pronunciar a nulidade pelo prazo de 24 meses, da Lei n. 7.619, de 30 de março de 2000, do Estado da Bahia". Ação Direta de Inconstitucionalidade 2.240/BA. Rel. Min. Eros Grau. Julgamento: 8 mai 2007.
} 
E nosso Supremo Tribunal sempre inclinou nesse sentido ${ }^{8}$. Mas, diante das modulações apresentadas e com prisma na anulabilidade, permitir-se-ia que a mudança de parâmetro atingisse a lei que antes era inconstitucional (NOVELINO, 2011, p.155), desde que não tenha sido a mesma declarada com eficácia erga omnes.

Por sinal, foi esse o caminho adotado pelo legislador constituinte com a promulgação da Emenda Constitucional 57 que incluiu o artigo 96 no ADCT com a seguinte redação: "Ficam convalidados os atos de criação, fusão, incorporação e desmembramento de Municípios, cuja lei tenha sido publicada até 31 de dezembro de 2006, atendidos os requisitos estabelecidos na legislação do respectivo Estado à época de sua criação”, opondo-se frontalmente ao teor da EC 15 de 1996 que modificou o artigo 18, §4º da Constituição Federal $^{9}$.

Vê-se, pois, que no caso em questão, a solução é apresentada pela constitucionalização superveniente, mas não se negue a existência de diversos outros elementos a contornar o hard case que mereceriam análise dedicada não fosse a EC 57, tais como a segurança jurídica, a situação fática consolidada e a boa-fé objetiva. E chamamos essa atenção porque parece-nos que são elementos que devem ser considerados em outros casos quando não estiver presente a mudança do parâmetro constitucional.

Melhor dizendo, será possível salvar a lei inconstitucional mesmo quando a Constituição não for alterada para adequar a norma ao parâmetro?

Em primeiro lugar, deve-se frisar que se trata de uma situação absolutamente excepcional. Não deve a teoria servir de escudo ao legislador para perpetrar ofensas deliberadas ao texto constitucional, aguardando que a inércia, no futuro, consolide a ofensa e torne os atos válidos. Não deve uma teoria que busca a salvaguarda da Constituição de fato se prestar a justificar violações constitucionais, servindo de guarida às inconstitucionalidades.

No julgamento da ADI 2.240, em questão, o STF consignou que a situação de inconstitucionalidade se instalou pela força normativa dos fatos, mormente em vista da inércia do Legislativo em criar a lei complementar que regularia a criação de novos Municípios, o que, por si só, já se apresentava enquanto inconstitucionalidade por omissão. Vê-se que se o

\footnotetext{
${ }^{8}$ RE 390.840, rel. Min. Marco Aurélio, DJ 15.08.2006.

${ }^{9} \S 4^{\text {o }}$ A criação, a incorporação, a fusão e o desmembramento de Municípios, far-se-ão por lei estadual, dentro do período determinado por Lei Complementar Federal, e dependerão de consulta prévia, mediante plebiscito, às populações dos Municípios envolvidos, após divulgação dos Estudos de Viabilidade Municipal, apresentados e publicados na forma da lei.
} 
Direito não puder acompanhar os fatos, estes continuarão caminhando mesmo contra o Direito.

Ademais, a situação fática se instalou com aparente respeito às populações envolvidas e à decisão política de criação e manutenção municipal ou, como diria Jellinek (2000, p.319), a partir da "força normativa dos fatos" (normative Kraft dês Faktischen), isto é, “[...] aquilo que permite compreender a origem e a existência da ordem jurídica, pois na vida do Estado as relações reais precedem as normas em função delas produzidas" (VIEIRA; BRASIL, 2007, p.306-307).

Ao depois, deve-se salientar que, embora na seara pública, a análise da inconstitucionalidade merece os olhos da "boa-fé objetiva" ou, na visão de Larenz (2001, p.91), da confiança, ressaltando-se que o ordenamento jurídico é um princípio ético, em que as pessoas devem mostrar-se fiéis aos seus propósitos e retilíneas na confiança que lhes fora outrora depositada ${ }^{10}$. Da mesma forma deve se portar o Estado. Se a situação se consolidou sob os olhos do próprio ente público, não caberia, posteriormente, alegar a impossibilidade de correção constitucional.

Nesse sentido, o magistério de Almiro do Couto e Silva (1988, p.21): "a faculdade que tem o Poder Público de anular seus próprios atos tem limite não apenas nos direitos subjetivos regularmente gerados, mas também no interesse em proteger a boa-fé e a confiança (Treu und Glauben) dos administrados".

Assim, parece-nos que a cicatrização constitucional pode se ofertar como resposta para as situações excepcionais que, ancoradas na confiança estatal, no princípio ético e na consolidação dos fatos, recomende a cura natural da Constituição, pois a formalidade à risca apresentará impactos desditosos ainda maiores.

\section{Limites e efeitos práticos na técnica de decisão}

\footnotetext{
10 “A Defesa da fidelidade e a manutenção da confiança formam o fundamento do tráfego jurídico e especialmente das relações jurídicas especiais. Em razão disso, o princípio (da boa-fé) não é limitado às relações jurídicas obrigacionais, mas se aplica segundo entendimento hoje pacífico, como um princípio geral do direito, aplicável sempre onde exista ou esteja preparada na relação jurídica especial. Diante desses requisitos, assim, também no Direito das Coisas, no Processo Civil e no Direito Público" (LARENZ, 1987, p.127).
} 
É evidente que a cicatrização constitucional enquanto pressuposto material para manutenção de situação fática consolidada não pode se prestar ao papel de servir como escudo para abusos em face da Constituição. Do contrário, qualquer violação à norma, por mais grave que fosse, poderia se proteger na teoria para que não fosse remediada. Este agir seria, claramente, uma afronta ao texto constitucional e à vontade popular que lhe escora.

Respeitar a Constituição é o primeiro pressuposto do constitucionalismo.

Toda Constituição traz em si não apenas a realidade fática de um povo, mas também seus anseios para um futuro por vezes nem tão próximos. E nem mesmo precisaria nomear tais Constituições como "dirigentes" ou "programáticas", como faria Canotilho (2007, p.217218) ao tratar das "normas-tarefa" e "normas-fim" da Constituição Portuguesa de 1976.

Tão menos que tais Constituições seriam "compromissórias" por fazerem parte de uma sociedade pluralista e complexa, expressando acordos frutos da convergência, dos acordos e das diferenças fáticas existentes.

Em verdade, é da natureza de toda lei fundamental refletir o aspecto socialeconômico de um povo inserto em determinado território, precipuamente no tocante ao seu sentido material ${ }^{11}$, sem perder de vista os objetivos e a implementação de certos programas em prol desse povo.

Essa conceituação é muito próxima daquela prevista por Bäulin, para quem a Constituição é a um só tempo "ordem fundamental" e "programa de ação":

Concretamente, além de ser a lei básica do Estado (perspectiva jurídica), a Constituição é também a norma fundamental ordenadora e conformadora da vida social (perspectiva sociopolítica), em cujo âmbito se formulam os fins sociais globais mais significativos, onde se fixam limites às tarefas da comunidade e onde, afinal, se ordena o processo político como um todo (MENDES; COELHO; BRANCO, 2008, p.8).

Ademais, conforme preceitua Miranda (2011, p.210), o que inaugura uma nova era constitucional não é a aprovação de uma Constituição formal, mas sim “[...] o corte ou a contraposição frente à situação ou ao regime até então vigente, em nome de uma nova ideia de Direito ou de um novo princípio de legitimidade, seja por meio de revolução, seja por outro meio".

\footnotetext{
${ }^{11}$ Sobre Constituição formal e material, ver: KELSEN, 2000, p. 182-183.
} 
O constitucionalista português, ainda, lembra que o poder constituinte material precede o formal porque a ideia de Direito vem antes da regra de Direito, “[...] o valor comanda a norma, a opção política fundamental a forma que elege para agir sobre os fatos, a legitimidade a legalidade" (MIRANDA, 2011, p.212).

Em um dos clássicos conceitos de Constituição, Lassale (1931, p.90) ressalta que a verdadeira Constituição do país deve refletir os "fatores reais e efetivos de poder" e tais Constituições escritas não possuem valor e não duram se não forem expressões fiéis dos fatores de poder que imperam na realidade social ${ }^{12}$.

Mas é bom de se ter em mente que a Constituição nem molda e nem engessa a realidade. De um lado, nenhuma lei tem o poder de, por si só, alterar as pretensões humanas. De outro lado, e por isso a Constituição deve conter essencialmente normas materialmente constitucionais, o mundo não se encerra no modelo constitucionalmente desenhado.

A Constituição é um projeto na medida em que, entre uma de suas finalidades, reside em si a materialização dos direitos que assegura, por serem frutos dos anseios soberanos do povo. Sem a eficácia dos direitos que ela promete não existe a menor razão de ser em sua existência. Ou seja, há natural perda de finalidade. Nesse sentido, Grau (1985, p.46): “Todos os seus preceitos hão de ter eficácia e aplicação imediatas, eis que somente assim deixará ela de cumprir o papel de instrumento de engodo e ilusão do povo". Ou, conforme Hesse (1991, p.16): "A Constituição adquire força normativa na medida em que logra realizar essa pretensão de eficácia".

E exatamente por tratar de questões que sejam substancialmente provindas dos anseios populares é que se poderia afirmar que a efetivação da Constituição é, em certa medida, a celebração do plano democrático.

Além disso, cumpre ressaltar que a "[...] constituição é uma lei proeminente que conforma o Estado" (CANOTILHO, 2007, p.89). Com essas palavras, Canotilho conclui que a Constituição só pode ser compreendida a partir do Estado, conferindo, nos termos da filosofia hegeliana e da juspublicística germânica, ordem ao mesmo.

O mestre de Coimbra, desenvolvendo a temática acerca da posição hierárquiconormativa superior da Constituição, ressalta que, excepcionando algumas questões do direito comunitário, há três expressões quanto ao tema.

\footnotetext{
${ }^{12}$ Ainda, a lição de Miranda (2011, p.32): "Na Constituição se plasma um determinado sistema de valores da vida pública, dos quais é depois indissociável. Um conjunto de princípios filosófico-jurídicos e filosóficopolíticos (embora de inspirações algo diversas) vem-na justificar e vem-na criar".
} 
Em primeiro lugar, a Constituição é dotada de uma "autoprimazia normativa", pelo fato das normas constitucionais constituírem uma lei superior que reconhece "o fundamento de validade em si própria”. Vale dizer, ela não depende de reconhecimento por outra norma, bastando, nos dizeres do professor português, que ela seja dotada de "normas democraticamente feitas e aceites (legitimidade processual democrática) e informadas por 'estruturas básicas de justiça' (legitimidade material)" (CANOTILHO, 2007, p.1147-1148).

Segundo, "as normas da constituição são normas de normas", sendo fonte de produção jurídica das normas infraconstitucionais (CANOTILHO, 2007, p.1148-1149). Esse processo, estampado formal e materialmente na Constituição, isto é, não apenas quanto ao modo de elaboração das leis, mas também determinando os limites substanciais de cada espécie normativa (vide, por exemplo, nosso artigo 146, assegurando que é reservado à lei complementar dispor sobre algumas questões tributárias). Evidentemente que, quanto ao controle de constitucionalidade, todas essas questões são resumidas às formalidades legais, no que toca respeito ao alinhamento da lei com a Constituição. Vale dizer, ainda que a norma ultrapasse seu limite material (ex: Lei Ordinária dispondo sobre prescrição tributária), a inconstitucionalidade será formal, por incompatibilidade entre a norma com a "norma de normas".

Terceiro, por estarem as normas constitucionais em uma posição topológica superior, os atos dos poderes públicos devem estar em conformidade com a Constituição. No aspecto de "determinante negativa", a Constituição se apresenta como limite às normas inferiores. Quanto ao aspecto de "determinante positiva", as normas constitucionais conformam a legislação inferior (CANOTILHO, 2007, p.1149). Este ponto, aliás, pode ser especialmente visualizado, no Brasil, na conformação do Código Civil de 2002 à Constituição e, mais recentemente, nos princípios que guiaram a estruturação do Novo Código de Processo Civil ${ }^{13}$.

Daí se vê, inequivocadamente, que a utilização da cicatrização para legitimar violações constitucionais, por si só, seria uma violação em si. Mais do que isso: uma violação à vontade do povo, ao projeto constitucional, às programações constitucionais e ao ordenamento jurídico como um todo, como visto acima.

Quais seriam, então, as situações que indicariam a utilização da teoria e quais os limites para sua aplicação?

${ }^{13}$ Especialmente interessante o artigo $1^{\circ}$ do referido diploma processual: "O processo civil será ordenado, disciplinado e interpretado conforme os valores e os princípios fundamentais estabelecidos na Constituição da República Federativa do Brasil, observando-se as disposições deste Código". 
Em primeiro lugar, é preciso ter em mente que a cicatrização não pode se operar sobre aquilo que é classificado por Schmitt (2001, p.47) como matéria eminentemente constitucional, isto é, a decisão política fundamental, as normas estruturantes de um Estado, que lhe dão confecção e identificam a força do poder constituinte originário.

Melhor dizendo, as normas fundamentais do Estado não podem ser agredidas e aceitas pela cicatrização, sob pena de subversão do próprio poder constituinte originário. Assim, os princípios fundamentais, os direitos fundamentais e a organização do Estado e dos Poderes não admitem, jamais, qualquer possibilidade de cura em vista de vícios de inconstitucionalidade.

Em segundo lugar, a cicatrização deve ser um mal menor frente à nulidade. Isto é, os efeitos da declaração de nulidade devem se mostrar mais perniciosos do que a manutenção da própria inconstitucionalidade. É o caso, antes citado, da nacionalidade dos filhos nascidos dos "casamentos mistos" na jurisprudência alemã. Da mesma forma, a manutenção dos distritos eleitorais equivocadamente divididos.

Vale dizer, os efeitos naturais da declaração de nulidade ou a anulabilidade trazem em si efeitos mais trágicos do que a própria violação da Constituição que, por sinal, já ocorrera e não aceita mais remédio. Há, nesse ponto, um predomínio, em termos de conflito, dos argumentos para manutenção dos fatos consolidados.

Em terceiro lugar, a situação deve estar consolidada pelos fatos. Uma inconstitucionalidade recente não admite a exceção. É necessário que toda uma situação jurídica tenha se erguida sobre a inconstitucionalidade aventada, de forma que minaria a segurança e a boa-fé das pessoas a declaração de nulidade, como ocorrera com o Município brasileiro de Luís Eduardo Magalhães.

Por fim, imprescindível que tenhamos em mente se tratar de situação excepcionalíssima, sob pena de transformar a Corte Constitucional em nítido legislador constituinte.

Em termos técnicos, duas seriam as saídas propostas para as decisões que, levando em consideração os elementos acima, resolvam materializar a cicatrização: a) declaração de inconstitucionalidade pretérita sem produção de efeitos; b) declaração de inconstitucionalidade pretérita com apelo ao legislador para correção futura.

Frise-se, antes de mais nada, que tais técnicas não se confundem com o fenômeno da cicatrização constitucional, mas dele decorrem para que, em termos de processo 
constitucional, possa ser proferida uma decisão. A cicatrização se opera no campo material, ao passo que as técnicas acima relacionadas correm no campo processual.

Ambas trabalham com o mesmo pressuposto: a declaração de inconstitucionalidade no passado. Isto é, reconhecem que a situação, quando se operou, realmente era ofensiva ao texto constitucional. Mas voltam essa declaração ao momento passado, em que se iniciou a violação. Isto significa que se reconhece apenas a inconstitucionalidade pretérita, mas não a atual, que se seguiu em continuidade àquela operada no passado. É nesse interim que ocorre a cicatrização. A situação que antes era inconstitucional, e até mesmo fora assim reconhecida, deixou de sê-lo, sem a necessidade de qualquer alteração no parâmetro constitucional. A cicatrização, por assim dizer, se opera no meio, entre o momento fundante da inconstitucionalidade e o momento da decisão do Tribunal.

O que difere as duas técnicas é a necessidade de correção ou a sua dispensa, em virtude de baixa ofensividade constitucional e possibilidade de interpretação não conflituosa com base em outros princípios constitucionais. De um lado, a situação em si já está remediada pela cicatrização. De outro, ela também cicatrizou, mas seria mais adequado operar constitucionalização superveniente, alterando o texto constitucional.

A “declaração de inconstitucionalidade pretérita sem produção de efeitos" tem por objeto simplesmente reconhecer que o tempo curou a ferida constitucional. Aquilo que era inconstitucional transformou-se em fato consolidado, não ofendendo mais a norma. E, sendo de baixa lesividade, além de ser possível recorrer aos princípios da própria Constituição para concluir de acordo com aquilo que antes era ofensa, não se recomenda qualquer ato legislativo. Basta apenas que a decisão reconheça o fato pretérito, mas não produza qualquer efeito.

Já a "declaração de inconstitucionalidade pretérita com apelo ao legislador para correção futura", embora também opere a referida cicatrização, reconhecendo a não continuidade da lesão à Constituição, em vista dos bens e da profundidade da ofensa, recomenda que, para o futuro, o legislador adapte o texto constitucional à realidade consolidada, de forma a conferir mais segurança jurídica aos envolvidos. Não produz qualquer efeito de nulidade, mas apenas o caráter pedagógico da decisão para avisar ao constituinte reformador que seria mais adequado mudar a Constituição. Se isto vier a ocorrer, teremos, então, hipótese de constitucionalização superveniente. A diferença é que já fora reconhecido, antes, a inconstitucionalidade da norma sem efeito de nulidade. 
Ambos os modelos, escorados pela proteção do cerne constitucional, repise-se, devem estar guiados pelos limites da cicatrização. E nos dois casos há um reconhecimento de que o tempo pode curar inclusive a Constituição.

\section{Conclusão}

Abrimos nosso texto com a pergunta acerca da cura da Constituição violada por atos de ofensa ao seu texto. Antes de mais nada, pretendemos saber se o tempo pode fechar as feridas da Constituição sem que esta seja ao menos modificada.

É que nas situações em que o parâmetro é alterado, como vimos, a teoria da constitucionalização superveniente pode oferecer boas respostas ao fenômeno, aceitando-se que, pela anulabilidade, a lei ainda não declarada inconstitucional mantenha-se intacta e já sob o novo parâmetro não possa mais receber a pecha de inconstitucionalidade.

A compreensão acerca da resposta ao questionamento perpassa pela desvinculação do nosso modelo misto da teoria da nulidade, amplamente aceita, mas já excepcionada entre nós. Como vimos, mesmo o modelo do judicial review tem se inclinado para a possibilidade de que a inconstitucionalidade não seja solucionada simplesmente pela nulidade.

Ademais, a análise acerca da lei inconstitucional invariavelmente nos carrega para o caminho do contexto fático e político da situação. Não que os fatos possam sempre justificar a conduta inconstitucional. E, na realidade, a cicatrização proposta é extremamente excepcional. Mas é preciso admitir que certas questões, em face da confiança e da boa-fé, a situação fática consolidada e a força normativa dos fatos possam fazer repensar a mera declaração de inconstitucionalidade.

É de bom grado sempre ressaltar a ideia de Miranda (2011, p.212), para quem “[...] a ideia de Direito precede a regra de Direito, o valor comanda a norma, a opção política fundamental a forma que elege para agir sobre os fatos, a legitimidade a legalidade".

Mesmo diante de questões não respondidas pela mudança de parâmetro constitucional - "constitucionalização superveniente" - não deve o intérprete se render à sedução simplista da nulidade. Por vezes, o próprio povo, que tanta base oferece ao poder 
constituinte originário, não pretende se dobrar à nulidade, aceitando o caminho que menos mal lhe traga.

Diante disso, aceitamos a ideia proposta, mas não para qualquer parcela do texto constitucional. Certos limites devem se impor para que a cicatrização não acabe frustrando o projeto constitucional.

Diante disso, a cicatrização encontra as seguintes restrições: a) não pode ocorrer em face de normas fundamentais da Constituição, como princípios fundamentais, direitos fundamentais e organização do Estado e dos Poderes; b) a cicatrização deve ser um mal útil, um malefício menor do que a declaração de nulidade. Noutras palavras, deve haver proporcionalidade na decisão que decide não determinar a nulidade; c) a situação inconstitucional deve estar consolidada pelos fatos, de forma a nulidade ofenderia a segurança jurídica e a boa-fé; d) a cicatrização somente pode ocorrer em situações excepcionalíssimas.

No tocante às técnicas de decisão propostas para a efetivação da cicatrização constitucional, apresentamos: a) declaração de inconstitucionalidade pretérita sem produção de efeitos; b) declaração de inconstitucionalidade pretérita com apelo ao legislador para correção futura.

Na primeira, reconhece-se que a situação era inconstitucional, mas que, no momento da decisão não o é mais, operando-se a cicatrização no tempo. Em vista da baixa ofensividade constitucional e da possibilidade de interpretação não conflituosa com base em outros princípios constitucionais, não se recomenda nenhuma atividade além da declaração de inconstitucionalidade pretérita. Os fatos, por si só, já tornaram a situação constitucional e até mesmo juridicamente consolidada.

Na segunda, o pressuposto é o mesmo. O que muda é que, diante dos bens ofendidos e da profundidade da ofensa, embora tenha havido cicatrização, é recomendável que o legislador constituinte adeque o texto constitucional à situação consolidada, o que, caso venha a ocorrer, instituirá constitucionalização superveniente.

De qualquer forma, deve-se sempre frisar que as situações de cicatrização, ao permitirem que o tempo cuide das lesões constitucionais, devem estar sempre disciplinadas pela ideia de que não se deve transformar o Judiciário em legitimador de ofensas à Constituição, mas um órgão que, diante da vida e da dignidade, dobra-se à constituição material, para reconhecer que os fatos podem mudar o Direito. 


\section{Referências}

BORGES DE OLIVEIRA, Emerson Ademir. Ativismo judicial e controle de constitucionalidade: impactos e efeitos na evolução da democracia. Curitiba: Juruá, 2015.

BULOS, Uadi Lâmego. Curso de Direito Constitucional. 5.ed. São Paulo: Saraiva, 2010.

CANOTILHO, J. J. Gomes. Direito Constitucional e teoria da Constituição. 7.e.d. Coimbra: Almedina, 2007.

COUTO E SILVA, Almiro do, "Os princípios da legalidade da Administração Pública e da segurança jurídica do Estado de Direito Contemporâneo”, Revista da Procuradoria-Geral do Estado, Porto Alegre, Instituto de Informática Jurídica, v.18, n.46, 1988, p.11-30.

GRAU, Eros Roberto. A constituinte e a Constituição que teremos. São Paulo: Revista dos Tribunais, 1985.

HESSE, Konrad. A força normativa da Constituição. Porto Alegre: Sérgio Antonio Fabris Editor, 1991.

JELLINEK, Georg. Teoria General del Estado. 2.ed. México: Fondo de Cultura Econômica, 2000.

KELSEN, Hans. Jurisdição constitucional. 2. ed. São Paulo: Martins Fontes, 2007.

. Teoria geral do Direito e do Estado. São Paulo: Martins Fontes, 2000.

LARENZ, Karl. Derecho Justo: Fundamentos de Ética Juridica. Madrid: Civitas, 2001.

Lehrbuch des Schuldrechts. München: Verlag C. H. Beck, 1987. Band I: Allgemeiner Teil.

LASSALE, Ferdinand. ¿Qué es una Constitucion? Madrid: Editorial Cenit, 1931.

MENDES, Gilmar Ferreira. A declaração de inconstitucionalidade sem a pronúncia da nulidade da lei - "Unvereinbarkitser Klärung" - na jurisprudência da Corte Constitucional Federal Alemã. Revista de Informação Legislativa, Brasília, a. 30, n.118, abr./jun. 1993, p.61-84.

Controle abstrato de constitucionalidade: ADI, ADC e ADO: comentários à Lei n. 9.868/99. São Paulo: Saraiva, 2012.

Saraiva, 2007.

Direitos fundamentais e controle de constitucionalidade. 3. ed. São Paulo:

; COELHO, Inocêncio Mártires; BRANCO, Paulo Gustavo Gonet. Curso de

Direito Constitucional. 3.ed. São Paulo: Saraiva, 2008. 
MIRANDA, Jorge. Teoria do Estado e da Constituição. 3.ed. Rio de Janeiro: Forense, 2011.

NOVELINO, Marcelo. Direito Constitucional. 5.ed. Rio de Janeiro: Forense: São Paulo: Método, 2011.

O'BRIEN, David M. Constitutional Law and Politics. New York: W. W. Norton, 1991. v. 2: Civil Rights and Civil Liberties.

PESTALOZZA, Christian. Noch verfassungsmässige. In: STARCK, Christian (Hrsg.)

Bundesverfassungsgericht und Grundgesetz: Festgabe aus Anlaß des 25jährigen Bestehens des Bundesverfassungsgerichtes. Tübingen: Mohr, 1976, v. I.

SCHMITT, Carl. Teoría de la Constitución. Madrid: Alianza Editorial, 2001.

URBANO, Maria Benedita. Curso de Justiça Constitucional: evolução histórica e modelos do controlo de constitucionalidade. 2.ed. Coimbra: Almedina, 2016.

VIEIRA, José Ribas; BRASIL, Deilton Ribeiro. A força normativa dos fatos como ferramenta do ativismo judicial utilizada para alargamento da competência do Supremo Tribunal Federal após a EC 45/04. Verba Juris, a.6, n.6, jan./dez. 2007, p.301-321.

WILLOUGHBY, Westel Woodbury. The constitutional law of the United States. New York: Baker, Voorhis, 1910. v. 1. 